\title{
今 世界の医療は?
}

\section{宇野 久光1) 菅野 義彦 ${ }^{2)}$ 林 正樹3) 吉田 直之 ${ }^{4)}$ \\ 川村 光信5)}

〔日内会誌 $100 ： 1464 \sim 1470 ， 2011 〕$

Key words dabigatran compared with warfarin, classification of chronic kidney disease, colorectal cancer after colonoscopy, graduate medical education in primary care, citation of prior research, patientcentered medical home neighbor, intervention for hypertension, hepatocellular carcinoma and hepatitis $\mathrm{C}$ virus, congestive heart failure, exenatide, missing data in clinical trials, universal health care coverage, advance directive law

最新の医学, 医療のトピックスが掲載された 米国内科学会 (ACP) 雑誌 (Annals of Internal Medicine) の目次と要旨 (抜粋) を ACP日本支 部Publication Committee委員が日本語訳し， $\mathrm{ACP}$ 日本支部のホームページに掲載しています. 医学, 医療の新たな情報を把握するのに有用で す.

URL : http://acpjc.naika.or.jp

\section{Annals of Internal Medicine紹介} 4 January 2011 Volume 154 Issue 1

\section{原著（Original Research）}

心房細動の脳卒中予防におけるダビガトランと ワルファリンの費用対効果の比較

Cost-effectiveness of dabigatran compared with warfarin for stroke prevention in atrial fibrillation. James V. Freeman, et al.

ダビガトランは心房細動患者における使用が
承認されている。この解析では, 65 歳以上の非 弁膜症性心房細動患者において，虚血性脳卒中 予防に対して，ダビガトランと用量調整したワ ルファリンの質調整生存年，費用，および費用 対効果を推定した。 ワルファリンと比較した増 分費用対効果比率は，低用量ダビガトランで質 調整生存年（QALY）あたり 51,229 ドル，高用 量ダビガトランでQALYあたり 45,372ドルであっ た。モデルはダビガトランの費用に影響された が，他の入力項目には比較的影響を受けなかっ たことから，ダビガトランはワルファリンの代 替薬として費用対効果に優れる可能性を示唆し ている.

蛋白尿と推定糸球体濾過量を用いた慢性腎臓病 患者のリスク分類 : コホート研究

Using proteinuria and estimated glomerular filtration rate to classify risk in patients with chronic kidney disease : a cohort study.

1) 日本赤十字広島看護大学，2）慶應義塾大学医学部，3）中頭病院，4）結核予防会複十字病院，5）東京聥信病院 Hisamitsu Uno ${ }^{1}$, Yoshihiko Kanno ${ }^{2}$, Masaki Hayashi ${ }^{3}$, Naoyuki Yoshida ${ }^{4)}$ and Mitsunobu Kawamura ${ }^{5)}:{ }^{1}$ Japan Red Cross Hiroshima College of Nursing, Japan, 2) School of Medicine, Keio University, Japan, 3) Nakagami Hospital, Japan, 4) Fukujuji Hospital, JATA, Japan and 5) Tokyo Teishin Hospital, Japan. 
Marcello Tonelli, et al.

Tonelliとその共同研究者は, 慢性腎臓病 (CKD) の新たなステージ分類法を開発した。推定糸球 体滤過量 (eGFR) と蛋白尿を合わせて用い, ど のような患者が慢性腎臓病を悪化させるか予測 するものである. eGFR単独のステージ分類と比 較して，この新しい方法は，悪化するグループ より，慢性腎臓病が悪化しない人を正確に再分 類することができたようだ. eGFRに蛋白尿を加 えることを考慮する新しいステージ分類法は, 不必要な患者紹介を減らすものの, 腎不全に進 行する一部の症例の患者紹介を遅らせるかもし れない.

大腸内視鏡検査による大腸癌の予防：住民母集 団を基盤とした症例対照研究

Protection from colorectal cancer after colonoscopy : a population based, case-control study. Hermann Brenner, et al.

住民母集団を対象として実施される大腸内視 鏡検査による大腸癌予防の度合いについては, 明らかになっていない. ドイッにおける今回の 研究では, 直前 10 年間の大腸内視鏡検査は, 大 腸癌発生リスクを $77 \%$ 低下した. 強力なリスク 抑制が，ほとんどの大腸癌進行ステージと年齢 において観察された．右側結腸と左側結腸の両 方で，年月の進行とともに徐々にリスク軽減の 度合いが増加した。

後腹膜線維症に対するプレドニゾンとミコフェ ノール酸モフェチルの併用療法 : ケースシリー ズ

Combined prednisone and mycophenolate mofetil treatment for retroperitoneal fibrosis : a case series. Paul J. Scheel Jr., et al.

今回のケースシリーズでは, 28 名の後腹膜線 維症患者に,プレドニゾンが 1 日 $40 \mathrm{mg}$ で開始さ れたのち 6 カ月かけて漸減, ミコフェノール酸
モフェチル $1,000 \mathrm{mg}$ は 1 日 2 回, 平均 24.3 力月 投与された。すべての患者で全身症状が軽減し た. $89 \%$ の患者で大動脈周囲の塊の大きさが $25 \%$ 以上縮小した. 上昇していた赤血球沈降速度や 血清クレアチニン濃度, 減少していたへモグロ ビン值は全患者で正常化した. 2 症例で疾患が再 発した。

医学と専門職 (Academia and the Profession) プライマリ・ケア卒後医学教育への薬物中毒医 学の組み込み：時節到来

Integrating addiction medicine into graduate medical education in primary care : the time has come. Patrick G. O’Connor, et al.

臨床医が薬物性疾患を認識せず，その結果と して，患者に不適切な医療が行われるというこ とがしばしば起きている。この認識不足に対処 するため, Betty Ford Institute（訳註：ベティー フォード研究所）は専門家会議を招集した。 そ こでは, プライマリ・ケア研修プログラムの薬 物乱用に関するトレーニングを向上させること

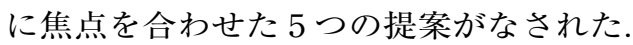

レビュー（Reviews）

系統的レビュー：進行大腸癌に対する抗EGF 受容体治療の効果にKRAS 遺伝子変異が及ぼす影 響

Systematic review: anti-epidermal growth factor receptor treatment effect modification by $K R A S$ mutations in advanced colorectal cancer.

Issa J. Dahabreh, et al.

抗EGF受容体抗体を用いた進行大腸癌治療の 予測バイオマーカーとして, KRAS遺伝子変異が 研究された. 本レビューではKRAS遺伝子の変異 状態が, 進行大腸癌に対する抗EGF受容体治療 を主体とした治療の効果に影響を及ぼすかどう か, そして, KRAS遺伝子の変異状態で臨床アウ トカムが予測できるかどうかについて評価した. 
$K R A S$ 遺伝子変異陽性患者では, 抗EGF受容体治 療は最善の支援治療や細胞障害性化学療法と比 較して, 全生存や疾患進行のない生存について 有意な利点はみられなかった。 しかしながら, $K R A S$ 遺伝子が野生型の患者では, 抗EGF受容体 治療が有用とする根拠がある。

\section{研究と報告の方法 (Research and Reporting Methods)}

無作為化比較試験の報告における, 以前の研究 の引用に関する系統的調査

A systematic examination of the citation of prior research in reports of randomized, controlled trials.

Karen A. Robinson and Steven N. Goodman

本研究は, 以前の試験から得られたエビデン スが, その後の無作為化比較試験 (RCTs) の論 文の中で，しばしば無視されていることを示唆 する.4つかそれ以上の試験を解析した 2004 年に発表された 227 のメ夕解析を対象とした本 レビューは, メ夕解析に含まれたそれぞれの報 告が, 1 年以上先行した試験を引用したかどうか を評価した。その結果, 関連性のある試験の 4 分の 1 未満しか引用されていなかった. 5 つかそ れ以上の関連のある以前の試験を有する 1,101 のRCTsのうち，23\% は全く引用せず， $23 \%$ は 1 つのみを引用していた. 関連のある以前の研究 の引用が久如したことの説明と結果を調査する ための研究が必要である.

\section{見解と意見 (Ideas and Opinions)}

\section{患者中心医療地区へようこそ}

Welcome to the patient-centered medical neighborhood. Christine Laine

近年, American College of Physicians（訳注 : 米国内科学会-ACP) の患者中心医療施設地区 (PCMH-N) の政策方針書は，医療提供の改善を 図るため, 患者中心医療施設 (PCMHs) が専門
医といかに関わって診療を行うべきかという概 要が記されている.この号ではACP・PCMH$\mathrm{N}$ 政策方針書に掲載された一般内科医と専門医 からのコメントを紹介する.

患者中心医療施設地区：プライマリ・ケア医の 視点

The patient-centered medical home neighbor : a primary care physician's view.

Christine A. Sinsky

Sinsky医師は患者中心医療地区（PCMHNs）が，我々を複雑な患者のケアを改善させる 方向に動かすと感じている. しかしながら, 機 能的PCMH-Nsに内蔵された個別のPCMHsを取 り囲む米国へルスケアシステムの変換にはよ りよい職員配置モデルや, 強力な電子情報機器, 支払い範囲内の質と効果に見合った意欲, そし て多くの患者と患者家族と地域が強力に結びつ く文化が必要であろう.

\section{患者中心医療地区：専門医の視点}

The patient-centered medical home neighbor : a subspecialty physician's view.

Hal F. Yee Jr.

Dr. YeeはPCMH-Nsをケアの連携や質の向上 に向けた重要なステップと見なしている. しか し, 高機能医療地区を構築するには改善の余地 がある.PCMHsと PCMH-Nsの間で提案される新 たな診療連携の形は, 従来の診療所訪問に依存 せず，革新的に相互関連するよう拡張しなけれ ばならず，推奨されるケアの連携の合意はより 標準化する必要があり, PCMHとPCMH-Nの実 践の間で本物の議論が実現されなければならな w.

\section{論評 (Editorials)}

慢性腎臓病の分類：一歩前進

Classification of chronic kidney disease : a 
step forward. Andrew S. Levey, et al.

本号では, Tonelliとその同僚らは, 慢性腎臓 病の患者のための推定糸球体滤過量 (eGFR) と 蛋白尿を組み合わせた新しい分類法を, eGFR だけを考慮する現行のシステムと比較した。論 説員はGFRのステージに蛋白尿を加えるとCKD の予後をより詳細に予測できると結論づけたが, 予後を測定する手段を使用することでCKDの管 理や患者のアウトカムを改善するかは, さらに 研究が必要である.

\section{大腸内視鏡検査：何が真実に結びつくのか？}

Colonoscopy: what does it take to get It "right”? David S. Weinberg

本号に掲載されたBrennerとその同僚の研究 は, 大腸内視鏡検查が左側だけでなく右側の結 腸直腸癌に対して実質上の予防効果があること を示し，我々に安心を与えてくれた。編集委員 は, 今回の結果と違い, なぜ最近の研究では期 待しているよりも低い確率の結腸直腸癌予防効 果を示したのかを議論し, さらに癌の発見と予 防に内視鏡検查の質が重要であることを論じる.

（本号の翻訳者：笠巻祐二, 西 慎一, 平野昌也, 赤真秀人, 川田秀一, 大島康雄, 䦎 康博, 勝田秀紀, 吉井康裕, 宮崎泰成, 菊地基雄, 以上翻訳順）

\section{January 2011 Volume 154 Issue 2}

\section{原著（Original Research）}

文化的に適切な経験談が血圧を改善する：無作 為化試験

Culturally appropriate storytelling to improve blood pressure : a randomized trial.

Thomas K. Houston, et al.

多くの高血圧患者では, 十分な血圧コントロー ルが達成されていない.この無作為化試験では, 299 例のアフリカ系アメリカ人の高血圧患者を,
通常の治療群と, 実際の高血圧患者の経験を提 示した 3 種類の双方向ビデオを視聴した治療群 とに割り当てた。検討開始時にコントロール不 良であった高血圧患者で, 経験（ビデオ）を視 聴した群では, 通常治療群に比べて, より良好 な血圧コントロールが得られた。本研究から， 高血圧に関する患者教育や血圧コントロールの 改善に関して, 経験談は効果的な方法であると 考えられる。

アメリカ合衆国のC型肝炎に罹患した退役軍人の 肝臓癌に対する検診施行率

Utilization of surveillance for hepatocellular carcinoma among hepatitis C virus-Infected veterans in the United States.

Jessica A. Davila, et al.

ガイドラインでは肝硬変患者に対して肝臓癌 のスクリーニングが推奨されている. しかし， 患者がどの程度の頻度で推奨されるスクリーニ ングを受けているかは明らかではない. Veterans Affairs（訳注：退役軍人局）のデータを解析し た今回の調査では，肝硬変を有する退役軍人の $12 \%$ が $\alpha$ フェトプロテイン, または腹部超音波 検查のどちらか一方を毎年 1 回施行していた. 58.5\% は不定期にスクリーニングを受けており， $29.5 \%$ は全くスクリーニングを行っていなかっ た.これらのデータは, 肝臓癌の危険性のある 患者に対するスクリーニング率を改善する戦略 が必要であることを示している.

心不全治療の業務プロセス, 転帰および費用と 病院規模との関連性

The association between hospital volume and processes, outcomes, and costs of care for congestive heart failure. Karen E. Joynt, et al.

治療の進歩にもかかわらず, 多くの心不全患 者は, 最善の転帰に至ってない. アメリカ合衆 国における心不全による入院患者のうち, 心不 
全の入院病床の多い病院に入院した患者では, 規模の小さい病院に入院した患者に比べて, 死 亡率が低く, 再入院が少なく, 医療費は高い. 如何なる医療行為が大規模の病院における有利 な転帰の原因であるかを理解することにより， すべての心不全患者の転帰を改善させる方策が 特定できるかもしれない.

基礎インスリン治療中の 2 型糖尿病患者に対す る 1 日 2 回のエキセナチド使用：無作為化比較 試験

Use of twice-daily exenatide in basal insulintreated patients with type 2 diabetes : a randomized, controlled trial. John B. Buse, et al.

この無作為化試験は, インスリン グラルギン 治療を行っている 2 型糖尿病患者でプラセボに 比して, エキセナチドの 1 日 2 回投与がへモグ ロビン $\mathrm{A}_{1 \mathrm{c}}$ を低下させるか否かを評価した． 30 週後, エキセナチドは, プラセボに比しへモグ ロビン $\mathrm{A}_{1 \mathrm{c}}$ と体重を減少させたが, 吐き気, 下痢, 嘔気や頭痛を生じた。両群間で, 低血糖頻度は 同等であった.

研究と報告の方法 (Research and Reporting Methods)

臨床試験における欠損データへの対応

Addressing missing data in clinical trials.

Thomas R. Fleming

欠損データは臨床試験による結果の信頼性と 解釈力を減弱させる. 久損データに対応するた めにしばしば用いられる方法は, たいてい不十 分である. 合理的なデータ補完の方法が有用か もしれないが, 検証不可能な仮定に依存してい る. 最善の方法はデータの久損を防ぐことであ る.この論文では, 追跡を向上させ, 久損デー 夕を減らすことが可能な臨床試験のデザイン, 実施, 分析の方法について議論している.
見解と意見 (Ideas and Opinions)

アメリカ合衆国における国民皆保険制度：この まま消滅するのか?

Universal health care coverage in the United States : is it "slip slidin' away"?

Robert B. Doherty

この解説では, Affordable Care Act (ACA) お よび 2010 年 11 月の選挙が医療保険改正に対す る影響についての討論に関して考察している.

著者らは, 医療保険を受ける権利が空前の危機 となっているにも関わらず, ACAの討論が, 医 療保険未加入者に焦点があっていないと言及し ている，医師たちは，全米国民に手ごろな医療 保険を提供することが必須であり，法律作成者 に保険の適用範囲を広げる機会を消滅させるこ とは許されない, と確信させるために重要な役 割を担うことができる.

医学と公衆衛生の話題 (Medicine and Public Issues)

法解釈に埋もれて：事前指示書法が臨床ケアに 及ぼした予期せぬ結果

Lost in translation: the unintended consequences of advance directive law on clinical care. Lesley S. Castillo, et al.

この論文は, 米国 50 州およびワシントンD.C. の事前指示書法を検証し, 識字能力の欠如, 代 理人の制限, 執行および証人に関する規約といっ た終末期のケアを阻害しうる障壁を明らかにし た。これらの障壁は, 十分な識字能力の欠如す るもの, 英語力を欠くもの, あるいはその双方 で事前指示書を理解できず執行することのでき ないもの，また信頼できる代理人を欠く可能性 のある同性または内縁のパートナー, そして助 けとなる人間のいない患者, 施設収容者, ある いはホームレスなど, 証人や適切な代理人を失っ ているかもしれない患者に対する特有のリスク を示している. 


\section{論評 (Editorials)}

\section{経験談：高血圧治療の新しい介入方法}

Storytelling : a novel intervention for hypertension.

Kimberly R. Myers and Michael J. Green

この研究でHoustonと同僚らは, ほかの患者の 経験談を聞くことによって, 血圧コントロール 不良のアフリカ系アメリカ人の血圧が低下する と報告している，著者らは，この知見に関する 考察，および医師たちが患者たちの経験談をほ かの母集団に日常的に治療に取り入れてよいの かどうかを, 考察している.

\section{2 型糖尿病における臨床的意義のある比較有効性 研究における潮時}

Time for clinically relevant comparative effectiveness studies in type 2 diabetes.

\section{David M. Nathan}

本号でBuseと同僚らは, 1 日 2 回エクセナチド を投与すると，プラセボと比較してインスリン グラルギンを投与されている 2 型糖尿病の患者 においてはへモグロビン $\mathrm{A}_{1 \mathrm{c}}$ レベルが低下すると 報告した，著者らは，この試験の限界について 考察している. また, 薬物治療がどんどん複雑 化していることから, 2 型糖尿病の最善の治療法 を検討するために長期比較有効性試験を勧めて いる.

\section{ACP Journal Club}

レビュー：PSAを用いる前立腺癌のスクリー ニングは, 死亡率を減少させない.

Review : prostate cancer screening using PSA does not decrease mortality.

48 時間のシサトラクリウム投与は, 早期・重 症ARDS (acute respiratory distress syndrome) の 90 日後の死亡率を減少させた.

48 hours of cisatracurium reduced 90-day mortality in patients with early, severe ARDS.

INR（international normalized ratio）を週 1 回自己検査することは, 月 1 回の診療所での検 査と比べて, 脳卒中, 重大な出血, あるいは死 亡の発生率を減少させなかった.

Weekly INR self-testing did not reduce stroke, major bleeding, or death more than monthly.

レビュー：Dダイマー陽性という結果は, 検査 のタイミング, カットポイント, あるいは患者 の年齢にかかわらず，特発性静脈血栓塞栓症初 発後の再発を予測する.

Review : positive D-dimer results predict recurrence after first unprovoked VTE regardless of test timing or cutpoint, or patient age.

INRの部分的調整は, 心房細動における重大な 出血という点で, ワーファリンと比較したダビ ガトランの利点に,いくらかの影響を及ぼした.

Local INR control had some effect on the benefits of dabigatran over warfarin for major bleeding in atrial fibrillation.

クロピドグレルまたはアスピリンの増量は, 心血管イベントを予防しなかった.

Increased doses of clopidogrel or aspirin did not prevent cardiovascular events.

症候性頸動脈狭窄における頸動脈ステント術 は, 内膜剥離術よりも短期間における脳卒中あ るいは死亡のリスクを増加させた.

Carotid artery stenting increased short-term risk for stroke or death more than endarterectomy in symptomatic carotid stenosis.

変形性関節症あるいは関節リウマチの患者に おいて，セレコキシブはオメプラゾールと併用 したジクロフェナックよりも消化管イベントを 減少させた.

Celecoxib reduced GI events more than diclofenac plus omeprazole in patients with osteoarthritis or rheumatoid arthritis.

アカンプロセートはアルコール依存の患者に 
おいて禁酒率を高める.

Review : acamprosate increases abstinence in patients with alcohol dependence.

レビュー：末梢動脈疾患における狭窄・閉塞 の診断において, 造影剂で強調したMRA（magnetic resonance angiography) は正確度が高い.

Review : contrast-enhanced MRA is highly accurate for diagnosing steno-occlusions in peripheral arterial disease.

レビュー：便中のカルプロテクチンは, 成人 において炎症性腸疾患の疑いをスクリーニング するのに正確であるが, 小児においては正確性 に乏しい.

Review : fecal calprotectin is accurate for screening for suspected IBD in adults but less so in children.

看護師により用いられるCanadian C-Spine Rule（訳注：カナダ式頸䯣の法則）は, 外傷患 者の頸髄損傷を正確に診断した.

The Canadian C-Spine Rule, used by nurses, accurately identified cervical-spine injury in patients with trauma.

（本号の翻訳者：塩田哲也, 松田正典, 吉田 博, 金原秀雄, 渡邊清高, 山前正臣, 市堰 肇, 松浦喜房, 浦野哲哉, 新谷英滋, 小山雄太, 以上翻訳順）

著者のCOI (conflicts of interest) 開示: 赤真秀人; 報酬 (エーザイ), 吉田 博; 講演料 (バイエル) 